\title{
Impact of Intellectual Capital Management and Human Capital Circulation on Business Practice at Macro- and Micro Level
}

\author{
Iryna Oleynikova, Zhanna Balabaniuk \\ Drahomanova Street, Kiev, Ukraine \\ iryna13579@gmail.com,zhannabalabaniuk@gmail.com
}

\begin{abstract}
Nowadays the main potential for growth comes from the ability to innovate and succeed with breakthrough ideas. However, despite growing importance of the subject matter, there are still no standard practices that would perform such a measurement and employ tendencies of human capital circulation. Various attempts have been made over recent years, but none have achieved general acceptance among experts in business field. Although there is no universally accepted theory, each has its own strengths and weaknesses in deriving approximate value of intellectual capital for various companies. In this work, we looked over some theories that have been suggested to estimate intellectual capital and analysed data from Ukrainian IT companies in order to prove how important measurement of intellectual capital and human capital circulation trends to allow for much better representation of an organisation's competitive position. Additionally, the impact of intellectual capital on various Key Performance Indicators, such as Economic Value Added and Weighted Average Cost of Capital, was examined with supporting financial analysis performed. The paper concludes with overview of methodological and managerial implications of the research, theoretical and practical limitations and possible improvements, and considerations for further research in the field of study.
\end{abstract}

Keywords: Intellectual Capital, Human Capital Circulation, Business Capitalization

\section{Introduction}

There is a great range of opportunities in the turbulent and highly dynamic contemporary global business world. Businesses today need to work to be more efficient and understand what drives their own capitalization growth. With growing focus on the intellectual development, business must adapt human capital recognition and circulation trends which will dramatically change the global job market and business practice in the nearest future. The 'global war for talents' gets tougher, as it becomes accepted that only creative and proactive talents are able to generate a sustainable competitive advantage. There are four main global trends which shape the future of intellectual capital Management and Human Capital Circulation we would like to highlight:

Forms of Diversity in the Workplace: Today one in ten employees are remote workers, freelancers or parttime workers. In 2014 the survey of business leaders at the Global Leadership Summit in London found that $34 \%$ of the companies surveyed expected more than half of their employees to be working remotely by 2020 . Additionally, $25 \%$ of the companies surveyed said that over three quarters of their workers would not be working in a traditional office by that time (Vanderkam, 2014). At the global level, the distribution of the labor forces between countries and regions is creating the opportunity to attract employees at any given moment from any part of the world. This means that, on the local level, every worker competes not only with other specialists in the country, but also with candidates from the global pool of employees. That is pushing companies to re-think talent management and intellectual capital policies. Businesses aim to create new ways of development of their and define standards of assessment and management of the companies' intellectual capital.

Robotics: The study of Martin's Oxford School in 2013 placed 47 percent of the total US workforce in the high-risk category due to advances in automation that will replace the jobs over the next several decades (Frey \& Osborne, 2013). The director of the Global Institute McKinsey speculated that $45 \%$ of the production activities performed by humans can be fully automated with the current technology (Chui, Manyika \& Miremadi, 2016). If this prediction comes true, we will get a situation when the structure of such jobs dramatically transforms. The ability to create innovative and technological breakthroughs will be key for business development, and thus knowledge assets and intellectual capital will become the main drivers of the new growing economics. 
Labor Mobility and Migration: The United Nations report from 2016 projects that by 2050 the world population will reach 9.7 billion. This means there will be 321 million migrant workers in the world in 2050, compared to 71 million in 2000 (Report of the Secretary-General Assembly of United Nations, 2016). The increase in population migration leads to the erosion of labor potential from some territories. For example, workers from developing countries tend to move to developed countries with high level of social protection guarantees. As a result, some countries need to create programs aimed at retaining the labor potential within the country and more favorable conditions for attracting workers. These factors influence the strategies that identify and exploit intellectual capital to create business opportunities.

Types and Sources of Financing Businesses: Nowadays, entering and scaling business is faster and easier. The tendencies are facilitated by many factors, such as the creation of more flexible organizational structures, the ability to attract remote workers, the capability to attract funding for startups through crowdfunding platforms, etc. At the global level, there will be an increase in individual entrepreneurial spirit. At the national level, countries will develop new conditions for expansion of entrepreneurship in certain areas. Consequently, the changes will lead to the creation and employment of innovative methods of valuating and managing intellectual capital.

\section{Literature Review}

We use the following definition of intellectual capital for research purposes:

"Intellectual capital is the group of knowledge assets that are attributed to an organization and most significantly contribute to an improved competitive position of this organization by adding value to defined key stakeholders" (Understanding corporate value: managing and reporting intellectual capital, 2002).

In deeper detail, the opportunities that a business can get by implementing intellectual capital concept and employing tendencies of human capital circulation are the following:

- Usage of business opportunities and the design of a long-term competitive advantage;

- Adjustment of traditional strategies towards innovative leadership;

- Deployment of critical thinking as a strategic lead of execution;

- Talent management across a knowledge sharing system;

- Reflection of the company's real value through the assessment of intellectual capital.

There are many methods of intellectual capital assessment that have been created by researches and practitioners working in the field. Some of them implement classification according to the general principles of valuation. These include the following groups of methods:

- $\quad$ Market Capitalization Methods - MCM;

- Return on Assets Methods - ROA;

- Direct Intellectual Capital Methods - DIC;

- Scorecard Methods - SC.

Other methods classify according to the valued objects, and include such methods as:

- Holistic;

- Atomistic.

Finally, the use of a monetary unit in the process of valuation grouping consists of two types:

- Monetary;

- Non- monetary' (Ramanauskaitè and Rudžionienè, 2013).

Referring to the paper by Sveiby (2004), there are 28 different models for Intellectual Capital Valuation (Sveiby, 2004). The most often used methods for the purpose of constructing reports on intellectual capital are Kaplan and Norton's Balanced Scorecard (Kaplan \& Norton, 1996), Karl-Erik Sveiby's Intangible Assets Monitor (Sveiby, 1997) and Skandia's Value Scheme (Edvinsson \& Malone, 1997). In our research, a number of methods of intellectual capital measurement and valuation were analyzed, specifically, Kaplan and Norton (1996), Brooking (1996), Sveiby (1997, 2004), Edvinsson and Malone (1997), Stewart (1997), Luthy (1998), Edvinsson (2000), Pulic (1998, 2000, 2004), Andriessen and Tissen (2000), and Andriessen (2000, 2001, 2005). 
Balanced Scorecard: The Balanced Scorecard looks at a business unit's performance from four perspectives: financial, customer, internal business process, and learning and growth. After the business defines the core business activities which require the most efficiency and create the main value for the business unit, the business evaluates the performance from each of the four perspectives. The Balanced Scorecard attempts to broaden the focus of the business to look beyond short-term financial information towards other intangible items that are implicated in the value generation process. This way, the business can encourage long-term development. The limits of The Balanced Scorecard method are: absence of clear correlation between the factors, lack of records for assessing the contribution of intellectual capital in comparison with other assets to general business result, focus on asset management rather than on asset financing, impossibility of forming a single and universal set of indicators for organizations of even one industry, and lack of estimations of model uncertainties and risks impacts.

Intangible Assets Monitor: The Intangible Assets Monitor (IAM) reports aim to present a more complete and realistic account of the performance and of the future business perspective. Intangible assets are classified by Sveiby into three parts: internal capital, external capital, and employee competence. Internal capital includes the organizational structure, legal parameters, manual systems, research and development, and software. External capital includes brands, and customer and supplier relationships. Employee competence includes education and training of the professional staff who are the principal generators of revenue. Each of the parts produces comparisons over one period to the next period. While the Intangible Assets Monitor (IAM) reports can provide account on one specific business, it is not possible to use the reports across businesses, even in the same sector. This approach is based on the range of knowledge, whose flow is a result of human effort and is dependent on the context specific to the subject. As such, it cannot be monetized objectively for a few businesses or over one sector.

Skandia Value Scheme (SVS): The Skandia Value Scheme (Edvinsson \& Malone, 1997) offers correlation between intellectual capital and financial (traditional accounting) capital in estimating the market value of the business. The business market value is seen as the result of combining the financial capital and the intellectual capital. Intellectual capital, in turn, is comprised of human capital, structural capital, customer capital, organizational capital, innovation capital, and process capital. However, the Skandia Value Scheme (SVS) does not include one single integrated indicator of the intellectual capital, the correlation between business valuation and business value. Additionally, the growth of the market value of a business is conditional on the impact of the new reporting on investors' expectations.

Market-to-Book Value Ratio: Some authors (Brooking, 1996; Edvinsson, 2000; Edvinsson \& Malone, 1997; Stewart, 1997) offered to estimate the intellectual capital as the difference between the market value of the company's shares and the book value of the assets reported on the balance sheet. Stewart argued that the market-to-book value ratio is easy to understand and can be quickly calculated (Stewart, 1997). However, the market value can be influenced by many different factors. For example, in different tax jurisdictions, companies can apply different business models to encourage investments into new fixed or intangible assets. Also, the assets reported in the balance sheet might be understated.

Tobin's "q": According to James Tobin (1969), intellectual capital is the ratio between a physical asset's market value and its replacement value.

The formula for Tobin's "q" is:

Businesses often use this method as a measure of corporate performance. It is possible to use it for individual assets and for all of the business. This method is also possible to use to compare the businesses with similar types of physical assets in the same industry.

Calculated intangible values (CIV): This method was created by Stewart (1997) and Luthy (1998) and was presented at the Asian Pacific Interdisciplinary Research as a tool for financial institutions to grant loans for knowledge based business. (CIV) is used for calculating the fair market value of a firm's intangible assets. The CIV method is connected to all types of capital assets (physical, financial, combined physical and financial and intangible). The CIV method evaluates financial efficiency derived from business' return on assets (ROA). As a result, it cannot estimate intangible values. This method can also be used to recognize the overall financial comparative advantage between businesses in the same industry. 
Value Added Intellectual Capital Coefficient (VAIC): The Value Creation Efficiency Analysis, called VAIC (Value Added Intellectual Coefficient) was developed by Ante Pulic $(1998,2000,2004)$. According to Pulic (2004), the model determines the size and the efficiency of intellectual capital. In the VAIC model, the most important indicator for business success is the value added. This method divides the intellectual capital into two major categories of human and structural capital. However, this model estimates the efficiency of the company's labor and capital investments. As a result, using the VAIC model does not produce results that correlate with a company's stock market value.

The Value Explorer: KPMG The Netherlands developed the method called The Value Explorer (Andriessen, 2001; Andriessen \& Tissen, 2000; Andriesson, 2005). A company should indicate the core competencies which identify the strategic importance of intellectual capital for the business. As was noted by Andriessen (2005), there are five steps to implementing The Value Explorer:

- The organizational core competencies are listed in order to identify the intellectual capital;

- A checklist is used to evaluate the value added, the sustainability, and the validity of these core competencies;

- The financial value of the intellectual capital is determined by attributing a portion of the expected normalized earnings to these core competencies;

- Recommendations are made to the management on possible ways to improve the value of the intellectual capital;

- A report is created using a value dashboard.

Despite having explored many methods of valuating the intellectual capital, we still cannot identify a universal one to employ for our research purposes. Methodologies of hiring and, thus, recording intangible assets can vary significantly depending on the industry. In this part of the research, a mixture of Investor's assigned market value, Value Added Intellectual Capital Coefficientand The Value Explorer methods of intellectual capital valuation has been considered as the main approach. The methods have been modified for the purposes of evaluating the companies' intellectual capital and their parts in considering the companies' current business performance.

The Industry and Research Overview: From the perspective of integration of the Ukrainian economy into the world economy, we must pay attention to the specifics of the development of the services sector. The Ukrainian service sector is slightly inferior in its growth to developed countries, primarily in the creation of the GDP in this sector - 62.8\% (in 2014) and 68.36 (2016) (Fakty Ukraine, 2016). Nevertheless, the service sector can contribute to a significant increase in the gross domestic product at a relatively low cost and shorter payback periods, and can also contribute to the development of the domestic market as the basis for sustained economic growth. Thus, Ukraine's economic development is characterized by an increase in the share of the services sector in the GDP and reflects the worldwide trend. The fastest growing sector, whose product is in demand not only in Ukraine, but also in foreign markets, is the IT sector. According to an independent macroeconomic survey conducted by $\mathrm{PwC}$ at the request of the IT-committee of the European Business Association, the export-oriented IT industry can double all indicators and generate up to 27.2 billion hryvnias of revenue to the state budget in 2020 (PwC. Doing business and investing in Ukraine, 2016).

Over the past four years, IT's contribution to Ukraine's GDP has increased from 0.6 to $3.3 \%$ (from $\$ 1.1$ billion to $\$ 2.7$ billion). This development was achieved due to the growth in the number of programmers from 42400 to 91700 people. However, the intensive growth of the industry due to the increase in the number of companies and specialists engaged in the industry is not the only factor that can lead to an increase in the sector's contribution to the country's GDP. Very important is the effective development of the industry through better use of the available human and intellectual resources, knowledge and implementation of the concept of creating, and managing intellectual capital. Importance of the industry is significant according to the numbers and trends. However, Ukrainian financial crises and lack of financing opportunities has already led to decreases in the industry growth and could stop further development. As a result, the industry will be dependent on external outsourcing models only. With such a huge business potential, it is crucial to create a full-cycled industry. 
To attract investors and finance the development and expansion of the industry it is necessary to make business understandable to the investors and this can be achieved through properly creating, evaluating, and managing the intellectual capital. Not all companies are ready to enter the markets of foreign loans, issue shares, bonds. And here is a serious problem of the company's financial statements, in which, as is typical for service companies, and, consequently, IT companies, there are practically no fixed assets. However, no enterprise can sustain and grow without the availability of financial resources and investments. In Ukraine, for the IT sector, attracting loans and investments by private investors at this stage of the industry development is a priority. Therefore, the main goal of the project was to create such a business description model in figures and to reflect these figures in the company's reporting system in order to show the potential investors and creditors the risk-free decision to invest in companies that do not have fixed assets, but there is a more important competitive advantage - intellectual capital - which can be recognized as intangible assets of the company. And it is the presence of intellectual capital that is the main factor of stable development and long-term competitive advantage of IT industry.

\section{Methodology}

For the reasons described above in the critical analysis of the methods for intellectual capital valuation (since no method can fully satisfy the need for a correct estimate of intellectual capital), during the project we used a combination of several methods to evaluate different groups of intellectual assets. In the course of the project, after evaluating the intellectual capital, certain operating expenses of the company were capitalized and transferred from current expenses to the value of intangible assets. Some results of the project are given in Tables 1-8. The data in the tables reflect the main trends in the company's performance, but are not entirely real. This is done to prevent the leakage of the company's financial information.

\section{Results}

In tables 1-4 financial indicators are shown before the intellectual capital evaluation.

Table 1: Profit and Loss Statement

\begin{tabular}{|c|c|c|c|c|c|}
\hline Year & 1 & 2 & 3 & 4 & 5 \\
\hline Sales & 284,000 & 212,800 & 318,000 & 425,000 & 467,500 \\
\hline Sales Growth & $147.9 \%$ & $-25.1 \%$ & $49.4 \%$ & $33.6 \%$ & $10.0 \%$ \\
\hline Cost of Sales & 204,480 & 172,368 & 248,040 & 361,250 & 406,725 \\
\hline Gross Profit & 79,520 & 40,432 & 69,960 & 63,750 & 60,775 \\
\hline Gross Margin & $28.0 \%$ & $19.0 \%$ & $22.0 \%$ & $15.0 \%$ & $13.0 \%$ \\
\hline $\mathrm{S}, \mathrm{G} \& \mathrm{~A}$ & 55,212 & 60,733 & 66,807 & 73,487 & 80,836 \\
\hline Depreciation \& Amortization & 15,205 & 15,205 & 15,205 & 15,205 & 15,205 \\
\hline Operating Profit & 9,103 & $(35,506)$ & $(12,052)$ & $(24,942)$ & $(35,266)$ \\
\hline Operating Margin & $3.2 \%$ & $-16.7 \%$ & $-3.8 \%$ & $-5.9 \%$ & $-7.5 \%$ \\
\hline Interest Expense & 2,819 & 1,823 & 1,802 & 1,869 & 2,064 \\
\hline Other (Income) Expense & - & $(65)$ & $(39)$ & 215 & 1,395 \\
\hline Pre-tax Profit & 6,284 & $(37,265)$ & $(13,815)$ & $(27,026)$ & $(38,725)$ \\
\hline Net Profit & 5,153 & $(30,557)$ & $(11,328)$ & $(22,161)$ & $(31,754)$ \\
\hline Net Profit Margin & $1.8 \%$ & $-14.4 \%$ & $-3.6 \%$ & $-5.2 \%$ & $-6.8 \%$ \\
\hline EBITDA & 24,308 & $(20,236)$ & 3,192 & $(9,953)$ & $(21,456)$ \\
\hline EBITDA Margin & $8.6 \%$ & $-9.5 \%$ & $1.0 \%$ & $-2.3 \%$ & $-4.6 \%$ \\
\hline
\end{tabular}


As can be seen from Tables 1-4, the company during the entire period of analysis is unprofitable, despite the growth in sales. However, operating expenses are growing at a faster pace. The capital employed is reduced, and the investments in R\&D remain unchanged, the economic added value is negative, which indicates the problems of long-term business development. However, the company is quite successful in terms of obtaining and executing contracts, and the growth of its capacity. Therefore, it was decided to analyze in more detail the operational costs in order to understand the reasons for their growth and reasons for the company's losses.

Table 2: Total Invested Capital and Cost of Capital

\begin{tabular}{|c|c|c|c|c|c|c|c|}
\hline Year & 1 & 2 & 3 & 4 & 5 & & \\
\hline \multicolumn{8}{|l|}{ Capital Employed: } \\
\hline Debt & 125,537 & 26,737 & 25,537 & 25,487 & 21,787 & & \\
\hline Equity & 15,513 & 22,000 & 26,700 & 28,700 & $(3,054)$ & & \\
\hline Book Value of Capital & 141,050 & 48,737 & 52,237 & 54,187 & 18,733 & & \\
\hline \multicolumn{8}{|l|}{ Adjustments: } \\
\hline Capitalized R\&D & 6,901 & 6,751 & 6,662 & 6,680 & 6,600 & & \\
\hline Depreciation & - & - & - & - & - & & \\
\hline Goodwill & - & - & - & - & - & & \\
\hline Present Value of Operating Leases & 10,558 & 12,645 & 11,678 & 9,700 & 7,400 & & \\
\hline Total Adjusted Capital & 158,509 & 68,132 & 70,577 & 70,566 & 32,732 & & \\
\hline Cost of Capital: & Pre-Tax & After-Tax & Weighting & & & & \\
\hline Debt (Kd) & $7.5 \%$ & $6.2 \%$ & $89 \%$ & $55 \%$ & $49 \%$ & $47 \%$ & $116 \%$ \\
\hline Equity & $12.0 \%$ & $12.0 \%$ & $11 \%$ & $45 \%$ & $51 \%$ & $53 \%$ & $-16 \%$ \\
\hline Weighted Average (Kw) & $8.0 \%$ & & $6.8 \%$ & $8.8 \%$ & $9.1 \%$ & $9.2 \%$ & $5.2 \%$ \\
\hline Tax Rate & $18.0 \%$ & & & & & & \\
\hline Year & & 1 & 2 & 3 & 4 & & 5 \\
\hline NOPAT & & 10,410 & $(26,541)$ & $(7,126)$ & $(16,915)$ & & $(27,797)$ \\
\hline Capital Cost & & 10,768 & 5,989 & 6,451 & 6,526 & & 1,701 \\
\hline Annual EVA & & (358) & $(32,531)$ & $(13,577)$ & $(23,441)$ & & $(29,498$ \\
\hline Current Value of Cumulative EVA & & (275) & $(26,985)$ & $(38,889)$ & $(60,839)$ & & $(90,337)$ \\
\hline NOPAT Return on Adjusted Capital & & $6.6 \%$ & $-39.0 \%$ & $-10.1 \%$ & $-24.0 \%$ & & $-84.9 \%$ \\
\hline Return Hurdle (cost of capital) & & $6.8 \%$ & $6.8 \%$ & $6.8 \%$ & $6.8 \%$ & & $6.8 \%$ \\
\hline Value Added (-Shortfall) & & $-0.2 \%$ & $-45.7 \%$ & $-16.9 \%$ & $-30.8 \%$ & & $-91.7 \%$ \\
\hline
\end{tabular}




\section{Table 4: Other Performance Indicators}

\begin{tabular}{lrrrrr}
\hline Year & $\mathbf{1}$ & $\mathbf{2}$ & $\mathbf{3}$ & $\mathbf{4}$ & $\mathbf{5}$ \\
\hline EBIT & 9,103 & $(35,441)$ & $(12,013)$ & $(25,158)$ & $(36,661)$ \\
EBITDA & 24,308 & $(20,301)$ & 3,153 & $(9,737)$ & $(20,061)$ \\
\hline Sales Growth & $147.9 \%$ & $-25.1 \%$ & $49.4 \%$ & $33.6 \%$ & $10.0 \%$ \\
Operating Earnings Growth & $31.8 \%$ & $-490.0 \%$ & $-66.1 \%$ & $107.0 \%$ & $41.4 \%$ \\
Net Earnings Growth & $-27.1 \%$ & $-693.0 \%$ & $-62.9 \%$ & $95.6 \%$ & $43.3 \%$ \\
Operating Margin & $3.2 \%$ & $-16.7 \%$ & $-3.8 \%$ & $-5.9 \%$ & $-7.5 \%$ \\
Net Profit Margin & $1.8 \%$ & $-14.4 \%$ & $-3.6 \%$ & $-5.2 \%$ & $-6.8 \%$ \\
EBITDA Margin & $8.6 \%$ & $-9.5 \%$ & $1.0 \%$ & $-2.3 \%$ & $-4.6 \%$ \\
Return on Equity (ROE) & $33.2 \%$ & $-138.9 \%$ & $-42.4 \%$ & $-77.2 \%$ & $-75.2 \%$ \\
Return on Net Assets (RONA) & $1.7 \%$ & $-53.6 \%$ & $-18.7 \%$ & $-35.1 \%$ & $-43.4 \%$ \\
Sales to Gross Fixed Assets & 1.0 & 2.1 & 2.8 & 3.5 & 3.4
\end{tabular}

The result of intellectual capital evaluation and recording in financial statements is shown in Tables 5-8.

Table 5: Profit and Loss Statement

\begin{tabular}{|c|c|c|c|c|c|}
\hline Year & 1 & 2 & 3 & 4 & 5 \\
\hline Sales & 284,000 & 212,800 & 318,000 & 425,000 & 467,500 \\
\hline Sales Growth & $147.9 \%$ & $-25.1 \%$ & $49.4 \%$ & $33.6 \%$ & $10.0 \%$ \\
\hline Cost of Sales & 88,051 & 111,720 & 166,950 & 223,125 & 245,438 \\
\hline Gross Profit & 195,949 & 101,080 & 151,050 & 201,875 & 222,063 \\
\hline Gross Margin & $69.0 \%$ & $47.5 \%$ & $47.5 \%$ & $47.5 \%$ & $47.5 \%$ \\
\hline$S, G \& A$ & 67,556 & 74,312 & 81,743 & 89,917 & 98,909 \\
\hline Depreciation \& Amortization & 11,123 & 12,192 & 18,540 & 21,750 & 23,025 \\
\hline Operating Profit & 117,270 & 14,576 & 50,767 & 90,208 & 100,129 \\
\hline Operating Margin & $41.3 \%$ & $6.8 \%$ & $16.0 \%$ & $21.2 \%$ & $21.4 \%$ \\
\hline Interest Expense & 2,819 & 1,823 & 1,802 & 1,869 & 2,064 \\
\hline Other (Income) Expense & - & (65) & (39) & 215 & 1,395 \\
\hline Pre-tax Profit & 114,451 & 12,818 & 49,004 & 88,124 & 96,670 \\
\hline Net Profit & 93,850 & 10,511 & 40,183 & 72,262 & 79,269 \\
\hline Net Profit Margin & $33.0 \%$ & $4.9 \%$ & $12.6 \%$ & $17.0 \%$ & $17.0 \%$ \\
\hline EBITDA & 128,393 & 26,833 & 69,346 & 111,743 & 121,759 \\
\hline EBITDA Margin & $45.2 \%$ & $12.6 \%$ & $21.8 \%$ & $26.3 \%$ & $26.0 \%$ \\
\hline
\end{tabular}


Table 6: Total Invested Capital and Cost of Capital

\begin{tabular}{|c|c|c|c|c|c|}
\hline Year & 1 & 2 & 3 & 4 & 5 \\
\hline \multicolumn{6}{|l|}{ Capital Employed: } \\
\hline Debt & 125,537 & 26,737 & 25,537 & 25,487 & 21,787 \\
\hline Equity & 209,087 & 62,879 & 84,148 & 103,001 & 182,270 \\
\hline Book Value of Capital & 334,624 & 89,616 & 109,685 & 128,488 & 204,057 \\
\hline \multicolumn{6}{|l|}{ Adjustments: } \\
\hline Capitalized R\&D & 6,901 & 6,751 & 6,662 & 6,680 & 6,600 \\
\hline Depreciation & - & - & - & - & - \\
\hline Goodwill & - & - & - & - & - \\
\hline Present Value of Operating Leases & 10,558 & 12,645 & 11,678 & 9,700 & 7,400 \\
\hline
\end{tabular}

\begin{tabular}{|c|c|c|c|c|c|c|}
\hline Cost of Capital: & Pre-Tax & After-Tax & Weighting & & & \\
\hline Debt (Kd) & $6.0 \%$ & $4.9 \%$ & $38 \%$ & $30 \%$ & $23 \%$ & $20 \%$ \\
\hline Equity & $12.0 \%$ & $12.0 \%$ & $62 \%$ & $70 \%$ & $77 \%$ & $80 \%$ \\
\hline Weighted Average (Kw) & $9.7 \%$ & & $9.3 \%$ & $9.9 \%$ & $10.4 \%$ & $10.6 \%$ \\
\hline Tax Rate & $18.0 \%$ & & & & & \\
\hline
\end{tabular}

\section{Table 7: Economic Value Added}

\begin{tabular}{|c|c|c|c|c|c|}
\hline Year & 1 & 2 & 3 & 4 & 5 \\
\hline NOPAT & 99,107 & 14,526 & 44,386 & 77,509 & 83,226 \\
\hline Capital Cost & 32,898 & 10,779 & 13,253 & 15,350 & 24,518 \\
\hline Annual EVA & 66,208 & 3,748 & 31,133 & 62,159 & 58,708 \\
\hline Current Value of Cumulative EVA & 46,316 & 49,183 & 75,222 & 132,070 & 190,778 \\
\hline NOPAT Return on Adjusted Capital & $28.1 \%$ & $13.3 \%$ & $34.7 \%$ & $53.5 \%$ & $38.2 \%$ \\
\hline Return Hurdle (cost of capital) & $9.3 \%$ & $9.3 \%$ & $9.3 \%$ & $9.3 \%$ & $9.3 \%$ \\
\hline Value Added (-Shortfall) & $18.8 \%$ & $4.0 \%$ & $25.3 \%$ & $44.2 \%$ & $28.8 \%$ \\
\hline
\end{tabular}


Table 8: Other Performance Indicators

\begin{tabular}{lrrrrr}
\hline EBIT & 117,270 & 14,641 & 50,806 & 89,993 & 98,734 \\
EBITDA & 128,393 & 26,768 & 69,307 & 111,958 & 123,154 \\
\hline Sales Growth & $147.9 \%$ & $-25.1 \%$ & $49.4 \%$ & $33.6 \%$ & $10.0 \%$ \\
Operating Earnings Growth & $1598.3 \%$ & $-87.6 \%$ & $248.3 \%$ & $77.7 \%$ & $11.0 \%$ \\
Net Earnings Growth & $1228.1 \%$ & $-88.8 \%$ & $282.3 \%$ & $79.8 \%$ & $9.7 \%$ \\
\hline Operating Margin & $41.3 \%$ & $6.8 \%$ & $16.0 \%$ & $21.2 \%$ & $21.4 \%$ \\
Net Profit Margin & $33.0 \%$ & $4.9 \%$ & $12.6 \%$ & $17.0 \%$ & $17.0 \%$ \\
EBITDA Margin & $45.2 \%$ & $12.6 \%$ & $21.8 \%$ & $26.3 \%$ & $26.0 \%$ \\
\hline Return on Equity (ROE) & $44.9 \%$ & $16.7 \%$ & $47.8 \%$ & $70.2 \%$ & $64.3 \%$ \\
Return on Net Assets (RONA) & $27.7 \%$ & $11.6 \%$ & $36.3 \%$ & $55.6 \%$ & $54.0 \%$ \\
\hline Sales to Gross Fixed Assets & 1.0 & 2.1 & 2.8 & 3.5 & 3.4
\end{tabular}

It is obvious that reflecting the intellectual capital as part of intangible assets leads to an increase in the value of the company's assets. Another positive effect, as noted, is the reduction in the costs of the period and the growth of the operating profit, all financial indicators affecting the credit rating of the company improve, allowing an increase in the rating by 2-3 positions on average. A consequence of improving the credit rating is the possibility of obtaining cheaper credit resources, which in turn reduces the weighted average cost of capital (WACC) and increases the economic added value (EVA). Moreover, the company's reporting transparently reflects the essence of the business, making the business more comprehensible and attractive for external creditors and investors. Eventually, some financial resources will be re-invested to alter business efficiency especially, to build flexible business models and structures, create remote teams and implement staff development activities, such as training, life-long learning approach and knowledge management system. It means the business will invest in future intensive growth and, as a result, get the intellectual capital upsurge.

\section{Conclusion and Recommendations for Future Research}

Taking into account the trends mentioned above, there will be some limitations and opportunities for further development and employment of macro and micro trends in human capital circulation for the purposes of intellectual capital advance, such as:

- Opportunities for decreasing the costs of employees. Businesses can transform organizational structure and make it more flexible by hiring remote workers and building virtual teams;

- Prospects for recruiting top-experts for projects, so that they can bring maximum benefit for the business being employed on part-time or project-type contracts;

- Scenarios for transforming performance systems throughout significantly increasing and connecting bonuses and variable parts of salaries to KPI's system and, thus, advancing performance and execution.

Being flexible for business is the crucial, but not only success factor. We need to build a system which can be adaptive and stable at the same time. In such systems, the concept of intellectual capital will become vital for the advancement of the business as it can ensure sustainable competitive advantages by employing key success factors, namely:

- Supervision of future business opportunities;

- Deployment of Knowledge Management System;

- Labor / Human resource management and advancement

- Constant execution of the ability to innovate. 
The preliminary results of the project showed that the effect of evaluating, managing and reflecting intellectual capital in reporting for an individual company can be significant. However, the macroeconomic effect, in the case of using approaches to the disclosure of information about intellectual capital, also exists, and it is connected with the possibility for the whole industry to get a new impetus to development. This possibility is grounded in the fact that banks and investment funds receive more transparent and understandable information and reporting, and are ready to lend to the industry. At the same time, the approach will give options for business to build a flexible talent management strategy utilizing trends of human capital circulation at global and local levels. Nevertheless, it is not necessary to keep silent about the complexity and ambiguity of the evaluation of intellectual capital for the purposes of disclosure and reflection in the financial statements. The uniform methodology, as before, does not exist and there are no qualitative preconditions for its harmonization and approval in the short term. Any uncertainty and ambiguity generates a different interpretation of figures and estimates of both present and future business development. It should be noted that an unambiguous answer about the future of intellectual capital is still not found. However, in our opinion, not even the ideal but maximally adapted assessment methodology can, and should be, used by high-tech companies and sectors with high added value and a small amount of fixed assets. Such an approach will ensure better manageability of companies' activities, understanding of the future prospects of businesses for both management and investors, and will become the basis for attracting the necessary financial resources. Finally, it is a good opportunity for companies to get long term competitive advantage, employ global human capital circulation tendencies, and ensure the growth of business efficiency at micro and macro levels.

\section{References}

Andersen, R. \& McLean, R. (2000). Accounting for the Creation of Value: Ongoing research project sponsored by the Canadian Institute of Chartered Accountants.

Andriessen, D. (2001). Weightless wealth: four modifications to standard IC theory. Journal of Intellectual Capital, 2, 204-214.

Andriessen, D. (2004). IC valuation and measurement: classifying the state of the art. Journal of Intellectual Capital, 5(2), 230-242.

Andriessen, D. (2004). Making Sense of Intellectual Capital: Designing a Method for the Valuation of Intangibles. Burlington, MA: Elsevier Butterworth Heinemann.

Andriessen, D. \& Tissen, R. (2000). Weightless Wealth: Finding Your Real Value in a Future of Intangible Assets. London: Financial Times/Prentice Hall.

Andriesson, D. (2005). Implementing the KPMG Value Explorer: Critical success factors for applying IC measurement tools. Journal of Intellectual Capital, 6(4), 474-488.

Brooking, A. (1996). Intellectual Capital: Core Assets for the Third Millennium. London, United Kingdom: Intl Thomson Business Press.

Chui, M., Manyika, J. \& Miremadi, M. (2016). Where machines could replace humans-and where they can't (yet). July 2016, [online] http://www.mckinsey.com/business-functions/digital-mckinsey/ourinsights/where-machines-could-replace-humans-and-where-they-cant-yet

Edvinsson, L. \& Malone, M. S. (1997). Intellectual Capital, Piatkus, London.

Edvinsson, L. (2000). Some perspectives on intangibles and intellectual capital 2000. Journal of Intellectual Capital, 1(1), 12-16.

Fakty Ukraine. (2016). IT-отрасльвУкраине: очеммногоговорят, номалознают. Ноябрь, 23, 2016, [online] http://fakty.ictv.ua/ru/ukraine/20161123-it-galuz-v-ukrayini-pro-shho-bagato-govoryat-ale-maloznayut/

Frey, C. \& Osborne, M. (2013). The Future of Employment: How Susceptible are Jobs to Computerisation. September 17, 2013,[online]http://www.oxfordmartin.ox.ac.uk/downloads/academic/The_Future_of_Employment. pdf

Kaplan, R. \& Norton, D. (1996). Using the Balanced Scorecard as a strategic management system. Harvard Business Review, January-February 2016, 71-79.

Luthy, D. H. (1998). Intellectual capital and its measurement. Paper presented at the Asian Pacific Interdisciplinary Research. 
Pulic, A. (1998). Measuring the performance of intellectual potential in Knowledge Economy. Paper presented at the 2nd World Congress on Measuring and Managing Intellectual Capital, McMaster University, Hamilton.

Pulic, A. (2000). VAIC ${ }^{\mathrm{TM}}$-an accounting tool for IC management. International Journal of Technology Management, 20(5/6/7/8), 702-714.

Pulic, A. (2004). Intellectual capital-does it create or destroy value? Measuring Business Excellence, 8(1), 6268.

PwC. Doing business and investing in Ukraine, 2016, [online] https://www.pwc.com/ua/en/survey/2016/assets/ukraine_doingbusiness_2016.pdf

Ramanauskaitè, A. \& Rudžionienè, K. (2013). Intellectual Capital Valuation: Methods and Their Classification, 2013, [online] http://www.journals.vu.lt/ekonomika/article/viewFile/1413/802

Report of the Secretary-General Assembly of United Nations. In safety and dignity: addressing large movements of refugees and migrants. 21 April 2016, [online] http://refugeesmigrants.un.org/sites/default/files/in_safety_and_dignity__addressing_large_movements_of_refugees_and_migrants.pdf

Sveiby, K. E. (1997). The New Organizational Wealth: Managing and Measuring Knowledge Based Assets, Berrett-Koehler Pub. Inc., San Francisco.

Sveiby, K. E. (2004). Methods for Measuring Intangibles [online] www.sveiby.com

Stewart T. A. (1997). Intellectual capital: the new wealth of organizations. New York, NY, USA: Doubleday.

Tobin, J. (1969). A general equilibrium approach to monetary theory. Journal of Money, Credit and Banking, $1(1), 15-2$.

Understanding corporate value: managing and reporting intellectual capital, 2002, [online] http://www.cimaglobal.com/Documents/ImportedDocuments/intellectualcapital.pdf

Vanderkam, L. (2014). Will Half Of People Be Working Remotely By 2020? Fast Company. August 14, 2014, [online]https://www.fastcompany.com/3034286/will-half-of-people-be-working-remotely-by-2020 